\title{
The Efficiency of the PQ4R Strategy in Understanding the Mathematical Proof among the Primary School Female Students
}

\author{
Rasha Ali Ennab $^{1} \quad$ Dr. Mamoon M Al-Shannag. Associate Professor ${ }^{2} \quad$ Dr.Ali Ahmad Al-Barakat .Professor ${ }^{3}$ \\ 1.Ministry of Education/ Matheatics Education \\ 2.Matheatics Education, Yarmouk University/Jordan \\ 3.Curriculum and Teaching Methods/ Yarmouk University/Jordan
}

\begin{abstract}
The purpose of the study is to examine the efficiency of the PQ4R strategy in understanding the mathematical proof among primary school female students. To achieve the purpose of the study, the analytical approach is used. The sample of the study consists of 40 female students divided into two groups, one is experimental and the other is control, with each group consisting of (20) students. As for the validity and reliability of the study instrument, they are validated as required by a group of highly respective validators. The results of the study show that there is an efficiency of the teaching strategy using (PQ4R) in improving the understanding of mathematical proof for female primary school students.
\end{abstract}

DOI: $10.7176 / \mathrm{JEP} / 11-16-09$

Publication date:June 30th 2020

\subsection{Introduction}

The information revolution age has recently witnessed a wide flow of knowledge and its technical applications, which forces the educational institution to pay attention to the knowledge structures following modern trends and theories. These knowledge structures are interested in building the thinking minds capable of building knowledge, and how to use it better. Thus, education must think by keeping pace with educational developments, including modifying its goals such as modifying the student's behavior, thinking directions, and knowledge structures, so that the learner attains the knowledge to understand himself deeply and works to apply it in solving the problems of the life. This matter has led to the development of the majority of knowledge and sciences, including mathematics, as a useful life subject for the individual throughout his school life, starting from school, going to university, and leaving for work.

The educational process's success is only done with the help of the teacher. The teacher, with his competencies, capabilities, desire, and inclination for education, can help the student master the learning and prepare him to acquire appropriate educational experiences. The teacher plays a prominent role in developing mathematics teaching for students in the public education stages. The more the teacher can teach the content and present it to students in the appropriate way and ignore the traditional teaching methods that rely on direct instruction, the students' understanding of what they learn becomes deeper (Astal, 2003).

Mathematics's effective teaching requires a teacher who can make appropriate decisions in the educational situation about mathematical knowledge, curriculum objectives, the classroom environment, and the needs of students. In light of the school mathematics principles and standards document, the mathematics teachers are required to understand what their students' level of knowledge and what they need to learn and then create suitable opportunities for effective learning. The teacher is the main focus of students 'success in mathematics, especially in the early elementary grades, alongside the fact that the student's success in mathematics depends on the skills, knowledge, and practices performed by the teacher (NCTM, 2000).

With a deep look to the development of mathematics curricula, it is seen that there are global efforts made to develop mathematics learning and teaching, and these efforts are a response to national and international requests calling for a review of mathematics objectives, teaching strategies, and methods for assessing their learning (Badawi, 2003). This necessitates a review of the teaching strategies used and focuses on indirect strategies whose focus is the student, its basis is extrapolation, inference, investigation, critical thinking, contemplative thinking, problem solving and mathematical thinking, and knowledge of the degree of the teacher's ability to use it. The teacher is obligated to select teaching strategies that help students to enrich their knowledge, develop their various thinking skills, and acquire them with methods of sound thinking (James, 2005).

PQ4R is a metacognition strategy and is an abbreviation of Preview, Question, Read, Reflect, Recite, Review. It is developed by Thomas and Robinson in 1972, where the letter (P) refers to ( Preview) which is a quick reading of the topic and knowledge of its basic features, and the letter (Q) refers to (Question), which is the questions that are presented by the student on the subject of the lesson. The first letter (R) refers to (Read), which is to read. The second letter (R) refers to (Reflect), which is to contemplate, and the third letter (R) refers to (Recite), which is to tell. The fourth letter (R) refers to (Review), which is to review (Rathus, 2012).

Attia (2013) explains that the importance of the strategy (PQ4R) lies in that it is one of the strategies of 
memorization techniques that helps students memorize, remember, and connect the information that they read to each other effectively. Connecting with information in an organized and sequential manner facilitates the student learning process, leads to more effective and deep learning, and access to real learning so that students realize the contents of reading texts, which helps them transfer their learning to other learning situations. Consequently, students will be able to self-learn by following the basic steps of this strategy. As in any other sciences, the learning process according to this strategy- is applied to mathematics- goes in the following stage of (Preview), which is reading topics and contents of Mathematics book where a look is taken at it, and at this stage, the student should look and think about the concepts of mathematics or problems in general through knowing the main ideas (Sudarman, 2009).

Sobkowwiaka argued that the process of review refers to gathering the information necessary to set goals and focus on the text, and the student must read the title and think about the topic that he might suggest to get more information. Also, the student is required to read the titles in bold and note and pay attention to any figures, as they build a framework in which details are attached during deep reading (as cited in Bibi, 2001).

Question stage: It can help the student in observing the data of mathematical problems or mathematical topics to notice the main objective of the problems or the topic by asking questions about the topic or problem. Questioning is a central feature of most classes (Ryan, 2004). Bibi (2011) believes that through the question stage of the PQ4R strategy, a student builds his questions based on reviews previously performed, and these questions are provided to be answered later in the reading stage.

Read stage: it enables the student to read the content or mathematical problems accurately. This stage is very important for the reason that the student can understand the content or problem by going through the reading station.

Reflect stage: it enables the student to link the previous information with the new information through contemplating and thinking about what he reads. The researchers believe that after going through this stage, the student can exclude the incorrect ideas through the considerations that he performs in the mathematical information (Sudarman, 2009).

Recite stage: it enables the student to try to hear the answers aloud about the questions he asked in the second stage.

Review stage: it is the final stage of the PQ4R strategy and aims at looking or checking again. The students deeply look at the main point of the text. After that, students make sure that the expected questions are answered and that the purpose of the author is quite understandable. Students review what they have learned by organizing and clarifying ideas encountered during reading. They can write critical summaries or notes or create a graphical representation to depict the relationship of the text and use this stage for deep learning (Logsden, 2007).

The PQ4R strategy contributes to refreshing previous knowledge, creating a kind of linkage between new ideas and previous ideas, organizing new information and facilitating its transition from short-term memory to long-term memory, encouraging integration and active interaction, increasing their ability to use the information and employ it in different educational situations, asking more questions and linking information and understanding it competently, and thus it serves as a bridge to mastering knowledge independently (Makur, 2019).

The PQ4R strategy has numerous goals such as developing the relationships among ideas by linking new information with previous information and remembering it, stimulating the left side of the brain for students by reading topics and then contemplating and reviewing the details of these topics, simplifying previous knowledge and awareness of organizing new information and reciting and listing basic information, accepting the information provided by presentation and lecturing, which raises and activates the left side of the brain, and making the student the focus of the educational process, which leads to forming positive trends among students towards education (Afaneh and Jaish, 2009).

Given the important role that mathematical proof plays in developing mathematical thinking and justification, the students must learn justification and build proof as part of an understanding of mathematics. Proof and logical arguments provide an essential aspect of mathematical competence because, without proof, it is not possible to verify the validity or invalidity of new ideas and speculations. Also, mathematical proof helps in verifying speculation, clarification, communication, and discovery (Kogce \& Yildiz, 2011).

The National Council of Teachers of Mathematics (NCTM, 2000) maintains that inference and proof are topics that should be examined and studies as early as in elementary school. This does not mean that they should learn to write formal proofs. It is recommended that students formulate speculations, communicate, explain, justify the logic, and develop these thinking skills through their mathematical experiences. If this recommendation is followed, students should be better prepared to write formal proofs by the time they reach high school.

The Council emphasizes the criteria for important operations such as the standard of proof, and the necessity of providing educational programs that enable students to build and investigate and verify mathematical speculations, realizing the importance of justification, thinking and proof as authentic aspects of 
mathematics, developing and evaluating mathematical arguments and proofs, and selecting and using different types of justifications and methods of proof because the importance of mathematical proof lies not only in being the only way to be convinced of the validity of a particular mathematical phrase but also in its multiple functions. Hemme (2010) shows that numerous researchers can verify the importance of mathematical proof in the teaching of mathematics and its important functions namely conviction, explanation, organization of results, communication, intellectual challenge, solving various problems. Therefore, one of the most significant justifications for teaching mathematical proof is the need for students to expand their knowledge and remove doubts about it, as it helps in developing students'ability to solve problems, increase their creative activity, and help them form mathematical mental structures (Abu Zina, 2003). Numerous studies have shown that high school and university students and pre-service teachers face real difficulties in their performance of mathematical proof (Senk, Thompson, \& Johnson 2008).

Tall (1992) shows that proof does not only include an understanding of the concept and mental processes, but also an awareness of how, why, and where the definition of the concept and mental processes is used. The concept of mathematical proof contains mental processes such as defining mathematical structures and constants, exploring and proposing assumptions, and organizing logical arguments (Ball, Hoyles, Jahnke \& MovshovitzHadar, 2002). The proof is central not only to justify mathematical knowledge but also to do and understand mathematics. Consequently, it is an important topic for all levels of education and is necessary to build and develop mathematical knowledge and mathematical communication (Stylianides, 2007). Of note, students not only encounter difficulties in building the proof, but they have also demonstrated that they have misunderstood the proof because they cannot apply due to misunderstanding the theory or concept (Weber \& Mejia-Ramos, 2011).

\subsection{Problem of the Study}

Through the work of one of the authors as a mathematics teacher and teaching for more than ten years, it is noticed that students suffer from a lack of understanding and mathematical proof construction, along with the weak acquisition of contemplative thinking skills in mathematics. The author's observations and field observations of students 'performance in mathematics are confirmed by the frustrating results and levels attained by the students of Jordanian schools in international tests such as (TIMSS) and (PISA). Besides, Hodds (2014) shows that students have the knowledge necessary to understand the proof but they need some guidance on how to apply their knowledge. Therefore, the problem of the study is to identify the efficiency of using the PQ4R strategy to improve the understanding of mathematical proof among primary school female students.

\subsection{Questions of the Study}

In light of the problem of the study, the following question is articulated:

- What is the efficiency of the PQ4R strategy in understanding the mathematical proof among the primary school female students?

\subsection{Objectives of the Study}

In light of the questions of the study, the following objective is formatted to answer the aforesaid questions.

- To identify the efficiency of the PQ4R strategy in understanding the mathematical proof among primary school female students.

\subsection{Significance of the Study}

The significance of the research is seen in the theoretical and applied areas related to the nature of the study. The study's theoretical significance is gained from the scarcity of Arab studies that examine the efficiency of using the PQ4R strategy to improve contemplative thinking and process of understanding of mathematical proof. The practical significance of this study shows that teachers can benefit from the application of its areas and uses, as the mathematics teacher plays a prominent role in developing mathematics teaching for students in the stages of education, and whenever the teacher masters the material that he teaches and presents it to students in the appropriate way, this reflects positively on students' understanding of what they learn more deeply as students' learning of mathematics is influenced by the experiences provided by the teacher. Importantly, this study is also important for curriculum authors to benefit from this study in designing modules based on the PQ4R strategy to achieve a greater number of learning outcomes (intellectual, emotional, and scientific), and hold training courses for teachers to use that strategy.

\subsection{Previous Studies}

Several previous studies have been done on PQ4R strategy, contemplative thinking, and mathematical proof in mathematics. In their study, Istiqomah, Rochmad \& Mulyono (2017) aims at investigating the effectiveness of the PQ4R learning model in improving creative thinking skills for learners in mathematics and identifying 
student classifications based on levels of creative thinking skills. They describe the misconception that impedes creative thinking skills at a low level of learning styles for learners, and the study population consists of seventhgrade students from SMP N 21 Semarang School in Indonesia. The study adopts the mixed curriculum (quantitative and qualitative). In quantitative data analysis, they use the t-test, z-test, and normalized gain test. As for the qualitative data, it is analyzed using the stages of data reduction, data presentation, and conclusions. The results show that effectiveness of the PQ4R learning model in improving the creative thinking ability of learners and classifications students are based on levels of creative thinking capabilities that have differences among many students at each level, and misconceptions that hinder creative thinking skills at a low level with learning styles: (a) visual pattern with a collection of four false indicators, (b) auditory pattern with a collection of three misunderstanding indicators, and (c) kinetic pattern with a collection of six false indicators .

Meanwhile. Gardenia, Herman, and Dahlan (2018) aim to reveal the impact of a strategy (PQ4R) on increasing Indonesian students' communication skills in mathematics. The study sample consists of (58) male and female students from the sixth-grade students divided into two groups: the experimental group consisting of (29) male and female students taught by a strategy (PQ4R) in their teaching of mathematics, and the control group consisting of (29) male and female students taught by the traditional way. To achieve the aim of the study, an experimental approach is used. The results of the study show that the strategy (PQ4R) has contributed positively to improving the level of communication skills among students in mathematics. The results also show that there are statistically significant differences at the level of communication skills in mathematics due to the group variable, and in favor of the experimental group. Also, in their 2018 study, Misykah, Sumantri \& Deasyanti (2018) aim at identifying the impact of strategy (PQ4R) and mental intelligence on higher thinking skills in mathematics for Indonesian elementary school students. The sample of the study consists of (46) of the fifth elementary class students divided into two groups: the experimental group, consisting of (24) male and female students taught by the strategy (PQ4R), and the control group consisting of (22) male and female students taught by in the traditional way. To achieve the aim of the study, an experimental approach is used. The results of the study show a positive effect of using the PQ4R strategy and a positive effect of (PQ4R) strategy and the mental intelligence of fifth-grade students on higher thinking skills.

Besides, the study of Makur (2019) conducted in Indonesia aims to identify the impact of strategy (PQ4R) and mathematical justification on the mathematical communication skills of high school students. The sample of the study consists of (76) male and female students from the secondary stage divided into an experimental group consisting of (40) students taught by a strategy (PQ4R), and (36) students taught traditionally. To achieve the aim of the study, an experimental approach is used. The results of the study show a positive impact of the (PQ4R) strategy and the mathematical justification skill on the students' mathematical communication skills.

As for (Sarimanah, Dewi, Efendi, \& Sallu 2019), their study aims to identify the effect of PQ4R strategy on improving Indonesian students' reading comprehension based on blended learning in elementary schools. The study sample consists of (20) students from the elementary stage. To achieve the aim of the study, an experimental approach is used. The results of the study show the presence of positive differences and statistical significance of strategy (PQ4R) at the level of reading comprehension based on blended learning among students due to the group variable and in favor of the experimental group, where digital reading materials are used using the strategy (PQ4R). The results of the study also show that students implement self-planning in the preparatory reading and asking questions, applying self-monitoring in the reading, contemplation and recite stages and selfevaluation at the review stage.

More importantly, in their 2019, Ndungo \& Majuma aim at exploring the level of students' abilities to use logical arguments and a conceptual map to build mathematical proofs. The study sample consists of (30) students from the mathematics major. They are divided into an experimental group consisting of (15) students taught by using a conceptual map to learn mathematics and mathematical proof theories, and a control group consisting of (15) students taught traditionally. To achieve the aim of the study, an experimental approach is used. The results of the study show that there are statistically significant differences for students' abilities to use logical arguments, and the conceptual map for building mathematical proofs due to the group variable, and in favor of the experimental group. The results also show that the developed conceptual map contributes to developing students' skills in mathematics, and enhances their ability to mathematical proof.

In light of the previous studies, studies and research related to using the (PQ4R) strategy are collected based on the positive impact of this strategy on teaching mathematics and other topics, whether in achievement, motivation, or developing critical thinking skills, creative thinking skills, higher thinking skills, mathematical thinking, mathematical communication, and mathematical problem-solving skills. It can be seen that the current study differs from previous studies as it examines the effectiveness of using the PQ4R strategy in understanding mathematical proof for the primary school female students.

\subsection{Terms of the Study}

The study adopts the following definitions: 
PQ4R strategy: it is procedurally defined as a strategy of metacognition that its use in mathematics education will stimulate memory as improving reading and memorizing for students to become more able to retain information and employ it in new learning situations. It is based on a set of sequential procedural steps such as having a look at introductory to the content of the Circle Unit and the proofs in it, asking questions about content and proofs, reading content and proofs, contemplating content and proofs, and reciting and reviewing evidence and content.

Mathematical proof: it is defined as "structured construction based on logical foundations and appropriate proof based on the rules and theories of mathematics to reach a specific result" (Abd Rabu, 2018: 215).

Understanding mathematical proof: it is procedurally defined as the student's ability to understand what the proof contains basic elements such as definitions, symbols, and shapes, define proofs of expression such as definitions and properties or conclusions, examine each step according to the rules of inference, and why the proof is correct, and know what the proof can prove. The understanding of mathematical proof is measured by the score obtained by the student in the scale of understanding mathematical proof in the Circle Unit prescribed to the tenth-grade students.

\subsection{Limitations of the Study}

This study is limited to explore the efficiency of using the PQ4R strategy in improving contemplative thinking and understanding mathematical proof, and its application is only limited to the Circle Unit. It is also limited to tenth grade students in Zarqa's First Education Directorate. Moreover, it is applied in the $1^{\text {st }}$ semester of the academic year 2019/2020.

\subsection{The Methodology of the Study}

To achieve the research objectives, an analytical approach is used.

\subsection{Study population}

The study population consists of all 40 female students of the tenth-grade at Arwa Bint Al-Hareth School in Zarqa's First Education Directorate during the first semester of the academic year 2019/2020.

\subsection{Study Sample}

The sample of the study consists of 40 female students divided into two groups, one is experimental and the other is control, with each group consisting of (20) students.

Table 1

Distribution of the Study Sample

\begin{tabular}{|l|l|l|}
\hline Group & Number & Percentage (\%) \\
\hline Control & $\mathbf{2 0}$ & $\mathbf{0 . 5 0}$ \\
\hline Experimental & $\mathbf{2 0}$ & $\mathbf{0 . 5 0}$ \\
\hline Total & $\mathbf{4 0}$ & $\mathbf{\% 1 0 0}$ \\
\hline
\end{tabular}

\subsection{Study Instrument}

To achieve the aims of the study, the mathematical proof understanding test is prepared as follows.

\subsubsection{Mathematical Proof Understanding Test (MPUT)}

To achieve the objectives of the study, a test is prepared in understanding the mathematical proof consisting in its final form of (44) questions divided into (4) dimensions, understanding the first proof, understanding the second proof, understanding the third proof, and understanding the fourth proof.

\subsubsection{Mathematical Proof Understanding Test Validity}

The test is validated in its initial form by presenting it to a group of validators with related knowledge, experience, and specialization in several Jordanian universities to identify the significance of the validators 'validity of the test and its suitability with the purposes of the study. The researchers regard the proposed modifications approved by $(80 \%)$ of the validators.

\subsubsection{Mathematical Proof Understanding Test Reliability}

The researchers calculate the mathematical proof understanding test reliability's coefficients applying it to a pilot sample consisting of (20) male and female students who do not belong to the application sample. Then, after two weeks of the first application, the application is repeated on the same sample, and the stability parameters of the return are calculated by the Pearson correlation coefficient between the two applications. The total reliability coefficient in this way is $(0.953)$, where the reliability of the internal consistency is calculated on the first application, and the total reliability coefficient in this way is (0.941), and the results are as in Table (2): 
Table 2

Coefficients of the Test-Retest and Internal Consistency for Each Dimension of Mathematical Proof Understanding Test and the Test as a Whole

\begin{tabular}{|l|l|l|l|l|}
\hline Dimension & Questions & No of Questions & Test-Retest & Cronbach's Alpha \\
\hline First proof understanding & $1-11$ & 11 & 0.849 & 0.865 \\
\hline Second proof understanding & $12-21$ & 10 & 0.869 & 0.836 \\
\hline Third proof understanding & $22-32$ & 11 & 0.885 & 0.856 \\
\hline Fourth proof understanding & $33-44$ & 12 & 0.868 & 0.809 \\
\hline Total score for the test & 44 & 0.953 & 0.941 \\
\hline
\end{tabular}

4.5.3 Mathematical Proof Test Correction

$-0=$ The answer is wrong, the justification is incorrect, and there is no reason for justification.

$-1=$ The answer is correct, the justification is incorrect, and there is no reason for justification.

- 2 = The answer is correct and the elements of justification provide proof of partially correct mathematical justification, which may contain minor mistakes in mathematical procedures, or the justification process is incomplete.

- 3 - The answer is correct and justification provides correct, clear and developed proof with logical justification communicated through the use of accurate and appropriate representations, symbols and/or graphics, and/or correct mathematical vocabularies that may contain minor mistakes that do not detract from the correct justification or demonstrate a comprehensive understanding.

\subsection{Teaching Program}

The researchers prepare a teaching program based on the PQ4R strategy concerning several relevant literature and previous studies.

\subsection{The General Objective of the Program}

The course aims to provide students with a set of skills based on the PQ4R strategy.

\subsection{Study Variables}

-Independent variable: PQ4R strategy

Dependent variable: mathematical proof understanding

\subsection{Statistical Processing}

To answer the study questions, the following are used:

- Arithmetic mean and standard deviations for the performance of the control and experimental study groups

- Calculation of Multivariate analysis of covariance (MANCOVA) to explore the differences in the performance of the members of the experimental group on the post-performance in the mathematical proof test.

- Bonferroni test is used for post comparisons to show the trend of statistical differences

- Eta Square is used to find the effect size of the efficiency of the PQ4R strategy.

\subsection{Results}

The results are presented according to the order of the study questions, as follows:

Results related to the main question, which states: What is the efficiency of the PQ4R strategy in understanding the mathematical proof among the primary school female students?

To answer the question, the significance of the differences among the arithmetic means for the performance of the study members on the post-mathematical proof understanding test is calculated according to the group variable (control, experimental), as follows. 
Table 3

Arithmetic Means and Standard Deviations for the Performance of the Study Members on the Post-mathematical Proof Understanding Test, according to the Group Variable (Control, Experimental)

\begin{tabular}{|l|l|l|l|l|l|l|}
\hline Group & $\begin{array}{l}\text { Descriptive } \\
\text { statistics }\end{array}$ & $\begin{array}{l}\text { First proof } \\
\text { understanding }\end{array}$ & $\begin{array}{l}\text { Second proof } \\
\text { understanding }\end{array}$ & $\begin{array}{l}\text { Third proof } \\
\text { understanding }\end{array}$ & $\begin{array}{l}\text { Fourth proof } \\
\text { understanding }\end{array}$ & $\begin{array}{l}\text { Total } \\
\text { score } \\
\text { for the } \\
\text { test }\end{array}$ \\
\hline \multirow{3}{*}{ Control } & AM & 7.50 & 7.75 & 6.95 & 8.95 & 31.15 \\
\cline { 2 - 7 } & $\begin{array}{l}\text { Number of } \\
\text { sample }\end{array}$ & 20 & 20 & 20 & 20 & 20 \\
\cline { 2 - 8 } & SD & 4.249 & 5.533 & 5.472 & 5.726 & 16.614 \\
\hline \multirow{2}{*}{ Experimental } & AM & 14.60 & 12.85 & 13.30 & 15.70 & 56.45 \\
\cline { 2 - 7 } & $\begin{array}{l}\text { Number of } \\
\text { sample }\end{array}$ & 20 & 20 & 20 & 20 & 20 \\
\cline { 2 - 8 } & SD & 5.205 & 6.352 & 7.760 & 5.868 & 19.403 \\
\hline
\end{tabular}

Table (3) shows that there are apparent differences between the post arithmetic means of the performance of the study members on understanding the mathematical proof according to the group variable (control, and experimental). To know the statistical significance of these apparent differences according to the group variable (control, and experimental), multivariate analysis of covariance (MANCOVA) is used as shown in Table (4).

Table 4

Results of Multivariate Analysis of Covariance (MANCOVA) for the Arithmetic Mean of the Performance of the Members in the Study Sample on the Post-mathematical Proof Understanding Test according to the group variable (control, experimental).

\begin{tabular}{|c|c|c|c|c|c|c|c|}
\hline $\begin{array}{ll}\text { Source } & \text { of } \\
\text { Variance } & \\
\end{array}$ & Skill & $\begin{array}{l}\begin{array}{l}\text { Sum of } \\
\text { square }\end{array} \\
\end{array}$ & $\begin{array}{l}\text { Dgree of } \\
\text { freedom }\end{array}$ & $\begin{array}{l}\text { Mean of } \\
\text { square }\end{array}$ & $\begin{array}{l}\text { Value } \\
\text { of } F\end{array}$ & $\begin{array}{l}\text { Statistical } \\
\text { significance }\end{array}$ & $\begin{array}{l}\text { Effect } \\
\text { Size }\end{array}$ \\
\hline \multirow{5}{*}{$\begin{array}{l}\text { Group } \\
\text { Wilks' Lambda } \\
\text { Value: .583 } \\
\text { Significance: .001 }\end{array}$} & FPU & 504.100 & 1 & 504.100 & 22.331 & .000 & .370 \\
\hline & SPU & 260.100 & 1 & 260.100 & 7.331 & .010 & .162 \\
\hline & TPU & 403.225 & 1 & 403.225 & 8.944 & .005 & .191 \\
\hline & FPU & 455.625 & 1 & 455.625 & 13.557 & .001 & .263 \\
\hline & $\begin{array}{l}\text { Total score } \\
\text { for the test }\end{array}$ & 6400.900 & 1 & 6400.900 & 19.620 & .000 & .341 \\
\hline \multirow[t]{5}{*}{ Error } & FPU & 857.800 & 38 & 22.574 & & & \\
\hline & SPU & 1348.300 & 38 & 35.482 & & & \\
\hline & TPU & 1713.150 & 38 & 45.083 & & & \\
\hline & FPU & 1277.150 & 38 & 33.609 & & & \\
\hline & $\begin{array}{l}\text { Total score } \\
\text { for the test }\end{array}$ & 12397.500 & 38 & 326.250 & & & \\
\hline \multirow[t]{5}{*}{ Modified Sum } & FPU & 1361.900 & 39 & & & & \\
\hline & SPU & 1608.400 & 39 & & & & \\
\hline & TPU & 2116.375 & 39 & & & & \\
\hline & FPU & 1732.775 & 39 & & & & \\
\hline & $\begin{array}{l}\text { Total score } \\
\text { for the test }\end{array}$ & 18798.400 & 39 & & & & \\
\hline
\end{tabular}

- FPU: First Proof Understanding

- SPU: Second Proof Understanding

- TPU: Third Proof Understanding

- FPU: Fourth Proof Understanding

Given the results of the analysis of variance in Table (4), there is a statistically significant difference at the level of statistical significance $(0.05=\mathrm{a})$ among the arithmetic means for the performance of the post-study members on the mathematical proof understanding test due to the group variable (control, experimental), where the value of the statistical significance of the total score for post-test and group is (.000). This value is less than the level of statistical significance $(0.05=\mathrm{a})$, which indicates the effectiveness of using the PQ4R strategy in improving the understanding of mathematical proof for students of the primary stage.

To determine the value of the statistically significant difference among the arithmetic means of the marks of the post-study members on the mathematical proof understanding test according to the group variable (control, experimental), and the direction of the differences in favor of which of the two groups, post comparisons are used with the Bonferroni test, and the results are as in the table (5). 
Table 5

Results of the Bonferroni Test for the Post Comparisons among the Arthmetic Means of the Marks of the Study Members on the Post-mathematical Proof Understanding According to the Group Variable (Control, Experimental).

\begin{tabular}{|c|c|c|c|c|c|}
\hline Skill & Group & $\begin{array}{l}\text { Modified } \\
\text { Mean }\end{array}$ & $\begin{array}{l}\text { Standard } \\
\text { Error }\end{array}$ & $\begin{array}{l}\text { Value of the difference } \\
\text { between the two arithmetic } \\
\text { means }\end{array}$ & $\begin{array}{l}\text { Statistical } \\
\text { significance }\end{array}$ \\
\hline \multirow{2}{*}{$\begin{array}{l}\text { First Proof } \\
\text { Undertanding }\end{array}$} & Control & 7.500 & 1.062 & \multirow[t]{2}{*}{$7.100^{*}$} & \multirow[t]{2}{*}{.000} \\
\hline & Experimental & 14.600 & 1.062 & & \\
\hline \multirow{2}{*}{$\begin{array}{l}\text { Second Proof } \\
\text { Understanding }\end{array}$} & Control & 7.750 & 1.332 & \multirow[t]{2}{*}{$5.100^{*}$} & \multirow[t]{2}{*}{.010} \\
\hline & Experimental & 12.850 & 1.332 & & \\
\hline \multirow{2}{*}{$\begin{array}{l}\text { Third Proof } \\
\text { Understanding }\end{array}$} & Control & 6.950 & 1.501 & \multirow[t]{2}{*}{$6.350 *$} & \multirow[t]{2}{*}{.005} \\
\hline & Experimental & 13.300 & 1.501 & & \\
\hline \multirow{2}{*}{$\begin{array}{l}\text { Fourth Proof } \\
\text { Understanding }\end{array}$} & Control & 8.950 & 1.296 & \multirow[t]{2}{*}{$6.750 *$} & \multirow[t]{2}{*}{.001} \\
\hline & Experimental & 15.700 & 1.296 & & \\
\hline \multirow{2}{*}{$\begin{array}{l}\text { Total score for the } \\
\text { test }\end{array}$} & Control & 31.150 & 4.039 & \multirow[t]{2}{*}{$25.300^{*}$} & \multirow[t]{2}{*}{.000} \\
\hline & Experimental & 56.450 & 4.039 & & \\
\hline
\end{tabular}

* Statistically significant at the level of statistical significance $(0.05=a)$

The results showed in Table (5) indicate the presence of statistically significant differences at the level of statistical significance $(0.05=a)$ on the mathematical proof understanding test between the performance of the members of the control and experimental groups, and in favor of the experimental group.

To identify the efficiency of using the PQ4R strategy to improve the understanding of mathematical proof for primary stage students, the effect size is calculated using the Eta Square. In light of Table (3), it is found that the total score of the mathematical proof understanding test is equal to $(0.341)$, which means that the teaching strategy variable of the PQ4R explains about $(34.1 \%)$ of the variance in the arithmetic mean of the study members' performance on the mathematical proof understanding test as a whole.

\subsection{Results Discussion}

The results show that there is an efficiency of the teaching strategy using (PQ4R) in improving the understanding of mathematical proof for female primary school students. This may be attributed to the fact that what distinguishes the (PQ4R) strategy is that it helps students in the process of memorizing and reciting information when they need it by increasing students' ability to organize and codify ideas and information, make them meaningful, and move them from short-term to long-term memory, and also enhance their ability to understand texts and develop their higher thinking skills.

This is also because the strategy helps in developing the ability of students to form questions and makes them more focused and aware of the content of the educational material. Besides, it contributes to developing students' learning skills by increasing their participation in the classroom and the ability to understand the curricula, as it helps to develop the skill of attention and focus, which reflects positively on the development of the level of the behavioral and cognitive process of students. Of note, it has contributed to motivating students to take advantage of their previous knowledge, and link it to new knowledge obtained from learning, gain effective learning and make greater use of their mental abilities. This strategy has also contributed to revitalizing previous knowledge, creating a kind of link between new ideas and previous ideas, organizing new information and facilitating its transfer from short-term memory to long-term memory, encouraging integration and interaction actively, and increases their ability to use Information and its use in various educational situations, and asking more questions and linking information and understanding them with full ability, and thus it serves as a bridge to mastering knowledge independently.

\subsection{Recommendations}

In light of the results of the current work, the following has been recommended:

* Teaching using the PQ4R strategy for all subjects and in all grades.

* Training teachers to use this strategy in the teaching process.

* Adopting other studies to measure other variables than the one covered by the current study.

\subsection{References}

Abd Rabu, Syed Muhammad. (2015). The effect of using brain-based learning strategies on developing mathematical proof and contemplative thinking and reducing math anxiety for third-grade middle school students. Mathematics Education Journal, 21 (3), 205-259.

Abu Zina, Farid. (2003). School mathematics curricula and teaching. Amman: Al Falah Library for Publishing 
and Distribution, Jordan.

Afaneh, Ezzo and Jaish, Youssef. (2009). Teaching and education with the two-sided brain. Amman: Dar AlThaqafa for Publishing and Distribution.

Astal, Ibrahim. (2003). Developing the professional competencies required for a mathematics teacher at Ajman University of Science and Technology in light of the standards of the National Council of Mathematics Teachers NCTM. Mathematics Pedagogies Journal, 6 (2), 47-76.

Attia, Mohsen, Ali. (2010). Beyond knowledge strategies in understanding the reading. Oman: Curriculum House for Publishing and Distribution.

Badawi, Ramadan. (2003). Strategies in teaching and evaluating mathematics learning. Amman: Dar Al-Fikr for Printing and Distribution.

Ball, D. L. Hoyles, C. Jahnke, H. N. \& Movshovitz-Hadar, N. (2002). The Teaching of Proof. Paper presented at the International Congress of Mathematicians. Beijing. China. 1(3). 907- 920.

Bibi, R. .(2011). Effect of PQ4R study strategy in scholastic achievement of secondary school students in Punjab (Pakistan).PhD, Foundation University College Of Liberal Arts And Sciences Islamabad.

Gardenia, N., Herman, T. \& Dahlan, T. (2018). PQ4R strategy (Preview, questions, read, reflection, recite, review) for mathematical communication ability. Advances in Social Science, Education and Humanities Research, 2(53) 322-327.

Hemme, K. (2010). Three styles characterizing mathematicians pedagogical perspectives on proof. Educational Studies in Mathematics International Journal, Springer, (75) 271-291.

Hodds, M. (2014). Improving proof comprehension in undergraduate mathematics, A Doctoral Thesis, Loughborough University.

Istiqomah, F, Rochmad, \& Mulyono. (2017). Mathematical creative thinking ability of the seventh grade students in terms of learning styles to the preview-question-read-reflect-recite-review (PQ4R) learning. Unnes Journal of Mathematics Education, 6(2), 258-267.

James, E. (2005). Constructing a math applications, curriculum-based assessment: an analysis of the relationship between applications problems, computation problems and criterion-referenced assessments. DAI- $B, 66(7)$ 39-33.

Kogce, D. \& Yildiz, C. (2011). A comparison of freshman and senior mathematics student teachers' views of proof concepts. Procedia Social and Behavioural Sciences, 15, 1266-1270.

Logsdon, A. (2007). Improve reading comprehension with the PQ4R strategy. Retrieved from Ann Logsdon.About.Com

Makur, A. (2019). The influence of PQ4R strategy and mathematical reasoning ability towards mathematical communication skills. Supremum Journal of Mathematics Education (SJME),3(1), 18-31.

Misykah, Z, Sumantri, S, \& Deasyanti, A. (2018). The effect of PQ4R strategy and intellectual intelligence on higher thinking ability in mathematics in elementary schools. International Journal of Advances in Scientific Research and Engineering (ijasre), 4 (9), 126-130.

NCTM. (2000). NCTM Principals \& Standards for School Mathematics. National Council of Teachers of Mathematics, USA.

Ndungo, I. \& Majuma, B. (2019). A concept map for teaching-learning logic and methods of proof: Enhancing students' abilities in constructing mathematical proofs. Merit Research Journal of Education and Review, $7(9), 101-108$.

Rathus, S.(2012). Psychology: Concepts and connections. Canada: TenthEdition,WadsworthCengage Learningproducts.

Ryan, K. (2004). Those Who can Teach. Boston: Houghton Mifflin Company.

Sarican, G. \& Akgunduz, D. (2018). The impact of integrated STEM education on academic achievement, reflective thinking skills towards problem solving and permanence in learning in science education. Cypriot Journal of Educational Sciences, 13(1), 94-107.

Setiawati, H. \& Corebima, A. (2018). Improving students' metacognitive skills through science learning by integrating PQ4R and TPS strategies at a senior high school in preparation. Journal of Turkish Science Education, 15(2), 95-106.

Stylianides, A. (2007). Proof and proving in school mathematics. Journal of Research in Mathematics Education, 38(3), 289-321.

Sudarman. (2009). Peningkatan Pemahaman Dan Daya Ingat Siswa Melalui strategi preview, question, read, reflect, recite, dan review (PQ4R). Journal Pendidikan Inovatif (JPI), 4( 2), 16-28.

Weber, K \& Mejia-Ramos, J. (2011). Why and how mathematicians read proofs: An exploratory study. Educational Studies in Mathematics, 76(3), 329-344. 